ROCZNIKI PEDAGOGICZNE

Tom 12(48), numer $3-2020$

DOI: https://doi.org/10.18290/rped20123-10

ANNA GUTOWSKA

\title{
ZESPÓŁ ASPERGERA \\ U OSOBY W OKRESIE PÓŹNEJ DOROSŁOŚCI. ANALIZA PRZYPADKU
}

\section{WSTĘP}

Celem artykułu jest opis przypadku 65-letniej kobiety z zespołem Aspergera. Podstawową tezą skłaniającą do badań było przekonanie, że starość to proces skomplikowany, niejednolity, silnie uwarunkowany jednostkowo i trudny do zamknięcia w kilku tylko kategoriach. Może mieć różne oblicza, tak jak różne są ludzkie biografie. Zmiany demograficzne zachodzące w polskim społeczeństwie stanowią i stanowić będą duże wyzwanie. Konieczne jest zatem zwrócenie uwagi na zróżnicowanie populacji osób starszych i na obciążenia, jakie mogą dotykać seniorów z chorobami, zaburzeniami współistniejącymi, np. tymi wynikającymi z zespołu Aspergera. Jest to zagadnienie niemal całkowicie zepchnięte na margines rozważań naukowych i bez wątpienia wymaga nie tylko zainteresowania, ale i eksploracji.

W omawianych badaniach wybór przypadku wynikał niejako z konieczności, a nie $\mathrm{z}$ wyjątkowości czy innych zasadnych kryteriów. Możliwość pozyskania do badań osób starszych z zespołem Aspergera okazała się bardzo ograniczona. Trudność ta wynika z co najmniej kilku powodów:

1. specyfika funkcjonowania osób z zespołem Aspergera,

2. brak instytucji skupiających starsze osoby z zespołem Aspergera,

3. brak dostępu do danych seniorów z zespołem Aspergera.

Przyjęto zatem kryterium dostępności, a kontakt uzyskano z polecenia. Zachęcenie do udziału w badaniach i nawiązanie kontaktu $\mathrm{z}$ badaną oraz

Dr AnNa Gutowska - Katedra Andragogiki i Gerontologii Społecznej, Wydział Nauk o Wychowaniu, Uniwersytet Łódzki; adres do korespondencji: ul. Pomorska 46/48, 91-408 Łódź; e-mail: anna.gutowska@uni.lodz.pl; ORCID: https://orcid.org/0000-0001-5258-8772. 
uzyskanie od niej zgody trwało 3 miesiące i związane było z przełamaniem wielu barier. Ostatecznie materiał badawczy udało się zebrać w ciągu czterech kolejnych spotkań, wykorzystując do tego wywiad swobodny z elementami narracyjno-biograficznymi, analizę dokumentów zastanych ${ }^{2}$ i obserwację uczestniczącą. Głównym celem badań było uzyskanie odpowiedzi na pytanie: jaka jest starość badanej kobiety z zespołem Aspergera?

Artykuł rozpoczyna się od wprowadzenia teoretycznego w poruszaną problematykę, gdzie przedstawiono najważniejsze zagadnienia dotyczące zespołu Aspergera i starzenia się. Opisano także podstawowe kwestie związane ze starością, starzeniem się (wybrane teorie starzenia się). Następnie uwzględniono charakterystykę badanej kobiety w kontekście jej sytuacji rodzinnej, bytowej, edukacyjno-zawodowej, zdrowotnej, relacji międzyludzkich i starości. Artykuł kończą wnioski i podsumowanie. Należy przy tym podkreślić, że opisany przypadek może być traktowany jedynie jako badanie pilotażowe i przygotowanie gruntu dla kolejnych eksploracji o szerszym zakresie.

\section{TEORETYCZNE PODSTAWY BADAŃ}

\section{Zespół Aspergera - ujęcie definicyjne, etiologia, kryteria diagnostyczne}

Zaburzenia charakterystyczne dla zespołu Aspergera (ZA) prawdopodobnie towarzyszyły ludzkości od wieków. Jako osobny syndrom chorobowy zespół został opisany stosunkowo niedawno, a tym, który stworzył jego charakterystykę, był austriacki pediatra i psychiatra - Hans Asperger. W publikacji z 1944 r. opisał sylwetki czterech chłopców: Fritza V., Harro L., Ernsta K. i Hellmutha L., których zachowanie wyróżniało się pod względem poznawczym, lingwistycznym i społecznym (Frith, 2008). Wyniki klinicznej diagnozy nietypowo rozwijających się chłopców stały się podstawą poszukiwań naukowych w obrębie jednostki dzisiaj określanej jako spektrum zaburzeń autystycznych, a przez Aspergera nazwanej autystyczną psychopatią (Delacato, 1995). Początkowo praca Aspergera na świecie nie wzbudziła zainteresowania, mimo kontynuacji badań i podejmowanych prób oddziaływań terapeutycznych, opisywanych w kolejnych publikacjach. W tym samym czasie badania prowadził Leo Kannera (1968), który wyróżnił z grupy wcześniej rozpoznawanych dziecięcych zaburzeń psychicznych (psychozy dziecięce,

\footnotetext{
${ }^{2}$ Analiza dotyczyła głównie dokumentów medycznych - uzyskano pisemną zgodę badanej na wykorzystanie do badań tego materiału.
} 
niedorozwój umysłowy) nową jednostkę chorobową i określił ją mianem „autyzmu wczesnodziecięcego" (ang. early infantile autism) ${ }^{3}$. Dopiero pod koniec lat 80. zaczęto częściej analizować wyniki badań Aspergera, a w roku 1981 r., już po jego śmierci, Lorna Wing po raz pierwszy użyła terminu Asperger's Syndrom. Za charakterystyczne objawy syndromu badaczka uznała: brak stanowczości, naiwność, nieodpowiednie, jednostronne zachowanie się, brak lub małą zdolność do nawiązywania przyjaźni, pedantyczną mowę, z powtórzeniami, ubogą niewerbalną komunikację, intensywną koncentrację na danych przedmiotach, niezdarność i zaburzoną koordynację ruchów oraz nierówną asymetryczną postawę (Attwood, 2006, s. 15).

Zespół (syndrom) Aspergera został uznany jako grupa w obrębie autyz$\mathrm{mu}^{4}$, która posiada własne kryteria diagnostyczne. Decyzja ta spowodowana była różnicą w obu przypadkach, polegającą na możliwości komunikowania się i postępach w rozwoju umysłowym. Ponadto stwierdzono, że zaburzenie jest bardziej powszechne niż klasyczny autyzm i może występować u osób, u których nie zdiagnozowano autyzmu (Maciarz, Biadasiewicz, 2005).

Zespół Aspergera (wraz z innymi zaburzeniami ze spektrum autyzmu) jest zaliczany do zaburzeń neurorozwojowych o skomplikowanej i wieloczynnikowej etiologii. Nie znaleziono konkretnej przyczyny powstawania tego typu zaburzeń. Naukowcy mają jednak pewne przypuszczenia co do czynników, które je powodują. Wśród nich wyróżnia się czynniki genetyczne, neurorozwojowe oraz wzajemnie na siebie oddziałujące biologiczne i środowiskowe (w tym np. okołoporodowe). Badania neuroobrazowe pokazały, że zespół Aspergera związany jest z dysfunkcją specyficznych struktur i systemów mózgowych. Wyniki badań neurologicznych funkcjonowania mózgu są zgodne z charakterystycznym dla zespołu Aspergera psychologicznym profilem społecznego myślenia, komunikacji, poznania i empatii, dzięki czemu wiemy, które struktury mózgowe działają w inny sposób (Attwood, 2006). A. Rynkiewicz pisze, że istnieją niepodważalne dowody na to, że zaburzenia ze spektrum autyzmu są zaburzeniami rozwojowymi mózgu i mają związek $\mathrm{z}$ nieprawidłowym funkcjonowaniem takich jego obszarów, jak:

- ciało migdałowate (odpowiada za kontrolowanie i generowanie emocji oraz za rozpoznawanie emocji u innych ludzi);

\footnotetext{
${ }^{3}$ Samo pojęcie ,autyzm” stworzył szwajcarski psychiatra Eugen Bleuler na początku XX w. wywodząc je z języka greckiego od słowa ,autos”, co znaczy „,sam”, „własne ja” i tym terminem nazwał osoby wycofane z życia społecznego, z ubogim wyrażaniem emocji.

${ }^{4}$ Spektrum autyzmu (ang. autism spectrum disorder), skrót - ASD.
} 
- hipokamp (bierze udział w procesie kodowania w czasie przenoszenia informacji z pamięci krótkotrwałej do pamięci trwałej, odpowiada za pamięć);

- móżdżek (napięcie mięśni, utrzymanie prawidłowej postawy ciała, równowagi, warunkuje wykonywanie ruchów precyzyjnych);

- płaty czołowe (odpowiadające za ruch, pamięć wyuczonych działań ruchowych, np. wyraz twarzy, schematy zachowań; warunkują ruch gałek ocznych zależnych od woli, odpowiadają za inicjowanie oraz planowanie działań, myślenie przyczynowo-skutkowe, analizę i kontrolę stanów emocjonalnych, mowę, ekspresję językową, podejmowanie decyzji, pamięć roboczą, kontrolowanie sekwencji zdarzeń);

- płaty skroniowe (odpowiadają za słuch i rozumienie mowy, za prozodię, gramatykę, rozpoznawanie obiektów, zapachów) (Rynkiewicz, 2009, s. 44, Rynkiewicz, Kulik, 2013).

Natomiast B. Rimland (1994), opierając się na teorii związanej z nagromadzeniem toksyn w organizmie (np. rtęci), nietolerancjami pokarmowymi, niedostatecznym odżywianiem, przewlekłymi infekcjami szukał przyczyn autyzmu w „całkowitych przeciążeniach całego organizmu”, w związku z szeregiem czynników zewnętrznych, działających na niedojrzały organizm noworodka czy niemowlęcia. Według tego autora czynnikami powodującymi pojawienie się zaburzeń ze spektrum autyzmu w podejściu biomedycznym są m.in.: uraz okołoporodowy, nieodwracalne infekcje ucha, zatok lub zakażenia paciorkowcami, chroniczne gorączki o nieznanej przyczynie, trudności z oddychaniem, silne lub przedłużone reakcje poszczepienne, zakażenie drożdżakowe, pogorszenie poziomu funkcjonowania po spożyciu ulepszaczy żywności, wrażliwość na środki chemiczne.

Jako że mechanizm powstawania zespołu Aspergera nie został jednoznacznie określony (chociaż wiadomo, że istotą tych zaburzeń są dysfunkcje mózgowe), głównym nurtem poszukiwań są teorie biologiczne (przyczyny genetyczne, uszkodzenie układu nerwowego, urazy okołoporodowe) i poznawcze. Naukowcy są zgodni co do tego, że w wielu przypadkach z uwagi na pewne predyspozycje genetyczne czynniki środowiskowe aktywują zachowania autystyczne (Pisula, 2012).

W Międzynarodowej Statystycznej Klasyfikacji Chorób i Problemów Zdrowotnych - ICD-10 zespół Aspergera definiuje się jako zaburzenie o niepewnej wartości nozologicznej, charakteryzujące się tymi samymi nieprawidłowościami w zakresie interakcji społecznych co autyzm oraz ograniczonym, stereotypowym repertuarem zainteresowań i aktywności, zaś kryteria diagnostyczne to: 
a) brak stwierdzonego opóźnienia w rozwoju mowy i funkcji poznawczych:

- wymawianie pojedynczych słów przed ukończeniem 2 roku życia, komunikacja przy użyciu zdań przed ukończeniem 3 roku życia;

- istnienie umiejętności praktycznych, zachowań adaptacyjnych oraz zainteresowania otoczeniem odpowiadające normom rozwojowym $\mathrm{w}$ pierwszych latach życia;

- szczególne umiejętności - przeważnie związane z nadmiernym zafascynowaniem jakimś tematem (kryterium niekonieczne do postawienia diagnozy);

b) przynajmniej dwie z poniższych trudności w relacjach społecznych:

- zaburzony kontakt wzrokowy, mimika, postawa ciała lub gestykulacja;

- trudności we właściwych relacjach z rówieśnikami;

- brak empatii - dziwaczne (nieadekwatne) reakcje na sytuacje społeczne, często słaba integracja zachowań społecznych, emocjonalnych, umiejętności komunikacji; brak potrzeby zabawy z innymi, posiadania wspólnych zainteresowań lub osiągnięć;

c) chociaż jedno z poniższych zachowań:

- stereotypowe i ścisłe zainteresowania, powtarzanie rytuałów i niepraktycznych czynności;

- powtarzające się ruchy (np. trzepotanie lub kręcenie rękami lub palcami, ruchy całego ciała);

- zafascynowanie częściami przedmiotów lub elementami materiałów (kolor, faktura, dźwięk);

d) wykluczenie innych zaburzeń rozwojowych, schizofrenii prostej, zaburzenia schizotypowego, obsesyjno-kompulsywnego, anankastycznego zaburzenia osobowości czy reaktywnego utrudnienia nawiązywania relacji społecznych w dzieciństwie lub nadmiernej łatwości w nawiązywaniu tych kontaktów (Kozdroń, 2015, s. 15-16).

W kolejnych wersjach klasyfikacji tj. DSM-V oraz ICD-11 zrezygnowano z terminu „całościowe zaburzenia rozwoju”, a trzy jednostki chorobowe: zaburzenia autystyczne, zespół Aspergera i PDD-NOS ${ }^{5}$ zastąpiono jedną spektrum zaburzeń autystycznych (ASD). Grupa ta zatem została podzielona ze względu na natężenie symptomów.

${ }^{5}$ PDD-NOS (Pervasive Developmental Disorder-Not Otherwise Specified) - wszechobecne zaburzenia rozwoju, nieokreślone inaczej, nazywane niekiedy nietypowym autyzmem, ponieważ kryteria zaburzenia autystycznego nie są spełnione, np. z powodu późnego wieku zachorowania, nietypowej symptomatologii lub podprogowej symptomatologii, lub wszystkie z nich. PDD-NOS jest uważany za łagodniejszą formę typowego autyzmu, co nie zawsze jest prawdą - niektóre cechy mogą być łagodniejsze, inne mogą być bardziej dotkliwe. 
Spektrum zaburzeń autystycznych obejmuje dwa zamiast, jak do tej pory, trzy obszary:

a) deficyty społeczno-komunikacyjne

b) uporczywe zainteresowania i powtarzalne zachowania (usunięty zostanie obszar związany z zaburzeniami języka i komunikacji, gdyż nie jest on charakterystyczny wyłącznie dla zaburzeń należących do spektrum autyzmu i nakłada się z trudnościami o charakterze wyłącznie językowym. Część osób z autyzmem - autyzm wysokofunkcjonujący i zespół Aspergera - nie doświadcza większych trudności w tym zakresie).

W klasyfikacji DSM-V mamy natomiast cztery kryteria diagnostyczne zaburzeń ze spektrum autyzmu

A. Trwałe deficyty w komunikacji i interakcji społecznej, obecne w wielu kontekstach i sytuacjach, przejawiające się obecnie lub w przeszłości, w następujących obszarach:

1. Deficyty w społeczno-emocjonalnej wzajemności (począwszy od nieprawidłowego podejścia społecznego i nieprowadzenia dwustronnej konwersacji, poprzez zmniejszenie dzielenia się zainteresowaniami, emocjami lub afektem, do nieumiejętności nawiązywania i reagowania na interakcje społeczne.

2. Deficyty w niewerbalnych zachowaniach komunikacyjnych wykorzystywanych do interakcji społecznych (począwszy od słabo zintegrowanej komunikacji werbalnej i niewerbalnej, poprzez nieprawidłowości w kontakcie wzrokowym, języku ciała oraz deficyty w rozumieniu i stosowaniu komunikacji niewerbalnej, do całkowitego braku mimiki i komunikacji niewerbalnej.

3. Deficyty w rozwoju, utrzymaniu i rozumieniu relacji, odpowiednio do poziomu rozwoju (począwszy od trudności w regulowaniu zachowań dostosowanych do różnych kontekstów społecznych, poprzez trudności w dzieleniu zabawy wyobrażeniowej i nawiązywaniu przyjaźni, do braku zainteresowania ludźmi. Nasilenie zaburzeń jest oparte na komunikacji społecznej i ograniczone powtarzającymi się wzorcami zachowań.

B. Ograniczone, powtarzające się wzorce zachowań, zainteresowań i aktywności, przejawiające się w co najmniej dwóch z poniższych zachowań, obecnie lub w przeszłości:

1. Stereotypowa lub powtarzalna mowa, stereotypowe ruchy lub stereotypowe posługiwanie się przedmiotami (proste stereotypie motoryczne, powtarzalne używanie przedmiotów, echolalia, idiosynkratyczne wykorzystywanie słów i wyrażeń.

\footnotetext{
${ }^{6}$ Na podstawie Diagnostic and Statistical Manual of Mental Disorders, Fifth Edition DSM V, American Psychiatric Assotiation, Washington 2013, thum. i oprac. Karolina Grzywacz.
} 
2. Nadmierne wykorzystanie rutyny, zrytualizowane wzory zachowań werbalnych lub niewerbalnych lub nadmierny opór wobec zmian (skrajny stres, zdenerwowanie w reakcji na małe zmiany, rytuały ruchowe, sztywne wzorce myślenia, nacisk na tę samą trasę lub identyczne jedzenie każdego dnia).

3. Bardzo ograniczone, utrwalone zainteresowania, które są nieprawidłowe w intensywności lub przedmiocie uwagi (silne przywiązanie do lub zainteresowanie niezwykłymi obiektami, zbyt ograniczone lub perseweracyjne zainteresowania).

4. Hiper lub hiporeaktywność na bodźce zmysłowe lub nietypowe zainteresowania sensorycznych aspektów otoczenia (widoczna obojętność na ból/ temperaturę, negatywna odpowiedź na konkretne dźwięki i tekstury, nadmierne wąchanie lub dotykanie przedmiotów, fascynacja światłem lub ruchem). Nasilenie zaburzeń jest oparte na komunikacji społecznej i ograniczone powtarzającymi się wzorcami zachowań.

C. Objawy muszą występować we wczesnym okresie rozwojowym (ale ich obecność nie może być oceniana zbyt wcześnie - przed okresem rozwojowym, w którym są społecznie wymagane. Objawy mogą być maskowane przez uczenie strategii w późniejszym okresie życia).

D. Objawy powodują klinicznie istotne upośledzenie w życiu społecznym, zawodowym lub w innych ważnych obszarach bieżącego funkcjonowania.

E. Zaburzenia nie można wytłumaczyć niepełnosprawnością intelektualną (zaburzenia rozwoju intelektualnego) lub globalnym opóźnieniem rozwoju. Niepełnosprawność intelektualna i zaburzenia ze spektrum autyzmu często współwystępują. Do diagnozy współwystępowania powyższych komunikacja społeczna powinna być poniżej oczekiwanego ogólnego poziomu rozwoju.

Diagnozowanie zespołu Aspergera u osób dorosłych ma miejsce stosunkowo krótko. Rzadko rozpoznawano chorobę, ponieważ ignorowano objawy, mniej nasilone niż w autyzmie, lub przypisywano je innym zaburzeniom. Wciąż odczuwalny jest niedostatek informacji o dorosłych z zaburzeniami typowymi dla ASD. Brakuje też danych na temat przebiegu tego zaburzenia w późniejszych fazach życia (Sławińska, 2014).

\section{Starość i starzenie się}

Analiza pojęć „starzenie się” i „starość”, z powodu swojej złożoności, wymaga odwoływania się do procesów biologicznych, psychologicznych i społecznych jako wzajemnie warunkujących pełny opis starzenia się i przeżywania starości. Procesy te są od siebie zależne. Trudno byłoby na potrzeby tego artykułu dokonać szczegółowej analizy tego zagadnienia. Warto jednak 
kolejny raz podkreślić, że starzenie się jest zjawiskiem powszechnym i dotyczy wszystkich ludzi i wszystkich społeczeństw. Na poziomie indywidualnym jest nieuchronnym procesem wpisanym w ludzkie życie. Jest to proces długotrwały i nieodwracalny, ale naturalny.

W literaturze przedmiotu opisano różne teorie starzenia i przystosowania się do starości. Na gruncie polskiej gerontologii najlepiej opisane zostały teoria aktywności i teoria wycofania. Są to tradycyjne już i dobrze znane podejścia, dlatego nie zostają tu przytoczone.

$\mathrm{Na}$ uwagę zasługuje także teoria opisana pod koniec lat 80 . XX wieku, a mianowicie teoria ciągłości ${ }^{7}$. Ta psychosocjologiczna koncepcja autorstwa Roberta Atchleya (1989) zakłada, że człowiek, adaptując się do zmian, w starości stara się utrzymywać pewien stan, wcześniej ukształtowane struktury, stara się zachowywać ciągłość. Pojęcia ciągłości używa się w dwóch znaczeniach: ciągłości wewnętrznej i zewnętrznej. W pierwszym - ciągłość odnosi się do zmian rozwojowych i związana jest z kształtującymi się, ale w miarę stałymi cechami osobowości (koncepcja ,ja”). Struktura wewnętrzna związana jest ze świadomością siebie, temperamentem, osobistymi preferencjami, wartościami, celami, strategią rozwiązywania problemów. To myśli, uczucia, emocje, które tworzą unikatową i wyjątkową całość. Ta struktura jest instrumentem selekcji informacji i narzędziem do podejmowania decyzji czy dokonywania wyborów (Muszyński, 2017, s. 52). W drugim znaczeniu ciągłość to struktura zewnętrzna, odnosząca się do środowiska, w którym żyje człowiek, do pełnionych ról społecznych, podejmowanych aktywności itp. Dostrzega się tu skłonność ludzi starszych do utrzymywania środowiska zewnętrznego w nienaruszonym stanie. Obie ciągłości zapewniają stabilizację i przewidywalność. Gwałtowne i nieprzewidywalne zmiany, zwane „nieciągłościami”, które mogą się zdarzać zarówno w sferze wewnętrznej, jak i zewnętrznej, wymagają radzenia sobie z nimi w celu odzyskania poczucia ciągłości.

Oprócz struktury zewnętrznej i wewnętrznej kluczowymi pojęciami dla teorii ciągłości są również ustalenie celów (głównie ukierunkowanych na rozwój jednostki w różnych obszarach życia) i utrzymanie zdolności adaptacyjnych, czyli świadomego dopasowania struktury wewnętrznej i zewnętrznej.

Oczywiście nie ma jednej uniwersalnej teorii wyjaśniającej mechanizmy przystosowania się do starości. Jak zauważa Steuden (2011), złożoność ludzkiego życia, bogactwo doświadczeń i ich odmienność stanowią o indywidu-

\footnotetext{
${ }^{7}$ Zwana także w polskiej literaturze teorią odpowiedników (Rembowski, 1984) i teorią kontynuacji (Halik, 2002).
} 
alnym i właściwym dla danej jednostki sposobie przystosowania do starości. Autorka artykułu odniesieniem interpretacyjnym uczyniła teorię, która stosunkowo rzadko wykorzystywana jest w badaniach gerontologicznych, tj. teorię ciągłości. $Z$ tej perspektywy spróbowała przyjrzeć się przystosowaniu do starości 65-letniej kobiety z zespołem Aspergera.

\section{OPIS PRZYPADKU}

Celem przeprowadzonych badań był opis i ukazanie funkcjonowania osoby z zespołem Aspergera w okresie późnej dorosłości z uwzględnieniem różnych aspektów jej życia (sytuacja rodzinna i bytowa, sytuacja edukacyjna i zawodowa, sytuacja zdrowotna, sfera relacji międzyludzkich). W centrum zainteresowań badawczych były także pytania o wpływ zaburzeń wynikających z ASD na proces starzenia się oraz wpływ procesu starzenia się na zaburzenie ASD. Materiał badawczy zebrano z trzech źródeł:

- wywiad swobodny z elementami narracyjno-biograficznymi (dyspozycje do wywiadu);

- analiza dokumentów zastanych (głównie dokumentacja medyczna);

- obserwacja uczestnicząca (dziennik obserwacji).

W trakcie kontaktów z badaną uwagę zwracały wyczerpujące wypowiedzi, ale mówienie jakby „w kierunku”, a nie „do” badacza. Dwukrotnie dało się także zaobserwować nieumiejętność rozpoznawania żartów. Konieczne było też dostosowanie się do stałego porządku dnia badanej i wręcz rygorystycznego przestrzegania godzin posiłków oraz innych schematów codzienności. Obserwacja ujawniła także dość ubogą komunikację niewerbalną - zakres mimiki twarzy, języka ciała trzeba uznać u badanej za raczej ograniczone. Ponadto również wygląd zewnętrzny zwracał uwagę - bardzo szczupła sylwetka, brak dbałości o fryzurę i ubiór.

\section{Sytuacja rodzinna i bytowa}

Badana kobieta wychowała się w rodzinie pełnej, ojciec zmarł 10 lat temu, matka żyje i mieszka z synem. Ma młodszego o 5 lat brata, który ze swoją rodziną mieszka w innym mieście. Utrzymują kontakt, ale raczej sporadyczny. Członkowie dalszej rodziny nie żyją lub nie mają kontaktu z badaną. Kobieta jest panną i nie ma dzieci. Mieszka sama, w dużym mieście, w bloku, w małym, jednopokojowym mieszkaniu z kuchnią i łazienką. Mieszka tu od ponad 40 lat. Lokal urządzony jest skromnie i widać, że dawno nie 
był odnawiany (nie mam pieniędzy na remonty, ale też nie lubię zmieniać, jak coś jest dobrze, to nie potrzeba). Badana posiada dużo książek, bibelotów, ale w mieszkaniu, mimo natłoku rzeczy, jest dość czysto. Książki są poukładane tematycznie i, jak mówi badana, wszystkie maja swoje state miejsce, inne rzeczy zreszta też, nic się nie zgubi. Widać szczególną dbałość o niektóre sprawy, np. ułożone książki, posegregowane według specyficznego klucza ubrania $\mathrm{w}$ szafie ( $w$ szafie mam same stare, ale dobre ciuchy, ale za to pouktadane porzadnie, tak jak lubię) i nieprzywiązywanie uwagi do innych, np. czystość podłogi, kurz na meblach.

Badana mieszka z psem. Kilka lat temu znalazła go na ulicy i przygarnęła. Jest on dla niej, jak mówi, towarzyszem życia. Widoczna jest głęboka więź uczuciowa między kobietą a zwierzęciem. Wychodzenie z nim na spacer oraz zakupy to niemal jedyne aktywności, które skutkują opuszczaniem domu i kontaktem z innymi ludźmi. Czynności te stanowią specyficzny rytuał, czyli odbywają się o stałych porach dnia, niezmiennie od lat.

\section{Ścieżka edukacyjna i zawodowa}

Badana ukończyła szkołę podstawową i 2 klasy technikum. W szkole starała się mieć zawsze dobre oceny, poświęcała dużo czasu na naukę. W ławce wolała siedzieć sama, bo jak mówi, siedzenie z innym dzieckiem bardzo mnie rozpraszało. Gdy wracała do domu, cały dzień spędzała na nauce, uczyłam się dobrze, ale na pamięć, a jeśli nie bytam idealnie przygotowana do lekcji, nie szłam do szkoły. Była sumienna, dużo się uczyła, bo chciałam umieć na szóstkę albo w ogóle. W drugiej klasie technikum przerwała naukę. Od tego czasu pozostawała na utrzymaniu rodziców, później zaczęła otrzymywać rentę socjalną z tytułu całkowitej niezdolności do pracy i samodzielnej egzystencji. Nigdy nie pracowała zawodowo.

\section{Sytuacja zdrowotna ${ }^{8}$}

Badana jako dziecko rozwijała się prawidłowo pod względem rozwoju psychoruchowego oraz mowy. Jednak już w przedszkolu wolała bawić się sama, co stopniowo przeradzało się w narastającą izolację społeczną. Stan psychiczny pogorszył się w 16 roku życia, kiedy badana zaczęła myć często ręce: potrafiłam myć ręce pót dnia, nie miałam już naskórka, bała się też dotyku, sierści zwierząt, korzystania z publicznych toalet, układała swoje

\footnotetext{
${ }^{8}$ Informacje o sytuacji zdrowotnej, pozyskane zostały z wywiadu oraz dokumentacji medycznej za pisemną zgodą badanej.
} 
rzeczy w określonym porządku i nikt nie mógł ich dotykać. Rodzice chcieli wówczas hospitalizować badaną w oddziale psychiatrycznym, jednak kobieta nie wyraziła na to zgody i uprosiła rodziców, by mogła zostać w domu. $\mathrm{Z}$ czasem stan psychiczny kobiety pogorszył się, zamknęła się w swoim pokoju i przestała dbać o higienę. Czas spędzała w pokoju na oglądaniu telewizji, myciu rąk i jedzeniu posiłków - koniecznie w określonych godzinach. $W$ pokoju miałam bałagan, bo nie wyrzucałam śmieci, wszystko uktadałam i przechowywałam. Badana nie wychodziła $\mathrm{z}$ domu, przebywała głównie w swoim pokoju, izolowała się od rodziny, nie utrzymywała kontaktów społecznych. Tłumaczyła to natrętną potrzebą mycia rąk po powrocie do domu. Uznała, że nie wychodząc, nie będzie czuła przymusu mycia. W domu myła ręce 4-5 razy dziennie przez kilkanaście minut, jednocześnie zaniedbując higienę pozostałych części ciała, twierdząc, że musiałaby w tym celu zejść do wspólnej łazienki. Jadała tylko wybrane produkty (surowe owoce, warzywa, ciemne pieczywo), posiłki przygotowywała i przynosiła jej do pokoju matka.

Rozpoczęła leczenie psychiatryczne, korzystała z indywidualnych konsultacji lekarskich w miejscu zamieszkania. Początkowo postawiono rozpoznanie schizofrenii prostej i zaburzeń obsesyjno-kompulsyjnych, zapisano leki, które badana przyjmowała nieregularnie i ostatecznie sama je odstawiała. Po pogorszeniu stanu zdrowia kobieta trafiła do szpitala psychiatrycznego, gdzie wykonano jej również badania psychologiczne. Wykazano ponad przeciętny poziom intelektualny, bardzo dobrą pamięć bezpośrednią słuchową oraz szeroki magazyn pamięci operacyjnej. Zdiagnozowano także zdolność do wytężonej pracy intelektualnej wymagającej dużego skupienia uwagi. Badana wykazała wysoki poziom wiedzy ogólnej i szeroki zakres zainteresowań oraz rozumienie sytuacji społecznych i panujących norm społeczno-kulturowych, co nie przekładało się na skuteczność jej działań edukacyjno-zawodowych oraz osobistych. Realne funkcjonowanie kobiety ukazywało obraz społecznego wycofania, dziwaczności zachowań i niewykorzystywania potencjału intelektualnego. Co ważne, badania ujawniły przedstawianie siebie w nadmiernie pozytywnym świetle oraz tworzenie nierealistycznego, faworyzującego obrazu własnego przystosowania. Na podstawie przeprowadzonej diagnostyki psychiatrycznej i psychologicznej wykluczono zaburzenia psychiczne ujęte $\mathrm{w}$ poprzedniej diagnozie $\mathrm{i}$ na podstawie całokształtu obrazu klinicznego postawiono rozpoznanie zespołu Aspergera. 


\section{Relacje międzyludzkie}

Badana nigdy nie była w związku uczuciowym i, jak podała, nie odczuwała też takiej potrzeby. Była i jest całkowicie wycofana z kontaktów społecznych, nie ma przyjaciół, znajomych. Kontakty z bratem, jego rodziną uważa za formalne. Najczęściej spędza czas, czytając książki, oglądając telewizję, najchętniej szuka informacji o zdrowym żywieniu. Temu zagadnieniu poświęca wiele uwagi.

O relacjach uczuciowych z mężczyznami mówi, że się nigdy nie angażowała, bo wiedziała, że jest trudnym przypadkiem, dziwakiem. Bliska relacja z drugim człowiekiem wymaga ujawnienia swojego prawdziwego oblicza, również tych najgorszych cech, a to często jest na tyle paraliżujące, że prowadzi do zaniechania czy ucieczki przed związkiem. Ponadto styl komunikacji osoby z zespołem Aspergera, często cechujący się obcesowością i bezkompromisowością, oraz trudności z odczytywaniem emocji stanowią istotne utrudnienie w budowaniu relacji. Ja bym nie umiała poznać, czy on kocha, czy nie kocha, co chce, co jest dobre, a co źle mówię. A to stres $i$ niepotrzebne komplikacje.

Badana nigdy nie miała przyjaciela/przyjaciółki. Nawet jako dziecko bytam typem samotnika, bytam inna, mi po prostu ludzie do szczęścia nie byli potrzebni. Ja chyba nawet nie wiem, co to znaczy mieć przyjaciela, czy być przyjacielem. Jak się z kimś spotykam raz $w$ tygodniu, to już jest przyjaźń? No jakoś nie wiem. A jeszcze te zarazki roznoszone, hatas, harmider, nie... nie... to nie dla mnie. A poza tym to skad tych ludzi brać? Z ulicy? Przeciez ja $w$ domu jestem, nie chodze $i$ zawsze tak byto. Wie Pani, ja przez lata wi$d z e$, że ludzie sq i ich nie ma, odchodza i przychodza, no tak jakoś..., to po co? Nie tęsknię za towarzystwem, nigdy nie tęskniłam i na pewno nie będę tęsknić, z innymi mi smutno, muszę się starać bardziej, a ja jestem najszczęśliwsza, jak nie muszę wychodzić z domu, chociaż codziennie przecież wychodze z moim pieskiem, ale to co innego.

Kwestia relacji międzyludzkich jawi się tu jako złożony problem. $Z$ jednej strony, widoczna jest trudność $z$ nawiązywaniem relacji z innymi osobami, z drugiej - kłopot z rozpoznawaniem wartości tych relacji (kiedy można uważać, że relacja jest przyjacielska), a z trzeciej - nieumiejętność utrzymywania relacji, związana z rozumieniem reguł rządzących przestrzenią stosunków międzyludzkich. Świat badanej jest silnie skoncentrowany na niej samej, a relacje z innymi budzą obawy, wywołują lęk przed niepowodzeniem i zmuszają do wysiłku kontrolowania się oraz „wchodzenia w rolę”, czyli udawania. Poza tym odrywają od własnych zainteresowań, swojego, bez- 
piecznego świata. Kobieta nie dostrzega celu takich związków, a więź emocjonalna nie jest wystarczającym czynnikiem motywującym do podejmowania wyzwania. Wymagania społeczne z tym związane są dla niej zbyt wielką przeszkodą. U badanej widoczny jest brak zdolności do tolerowania obecności innych osób oraz brak innych umiejętności społecznych, które bezpośrednio wiążą się z cechami osoby z zespołem Aspergera, a które z dużym prawdopodobieństwem utrwalały się dodatkowo w kolejnych latach życia.

\section{Starość i starzenie się}

Starość dla badanej nie jest jakimś szczególnym okresem w życiu. Przyjmuje zmiany ze zrozumieniem i specyficzną naturalnością. Nic się właściwie nie zmienito, co, że włosy siwe, albo oczy słabsze to przecież nic, takie normalne, oczywiste, jak u wszystkich, więc mnie nie zaskoczyto nic. Dostrzega jednak pewne zmiany, np. te związane ze sprawnością fizyczną, a dokładniej - odczuwaniem zmęczenia czy pogorszeniem widzenia. Poza tym kobieta deklarowała, że nie choruje i nie cierpi na jakieś dolegliwości zdrowotne wymagające przewlekłego leczenia: Mnie rzadko coś boli, jestem zdrowa, nie muszę biegać po lekarzach. Należy jednak zauważyć, że u osób z ASD stwierdza się dość często odmienne doświadczanie bólu oraz opisywanie go (Hendrickx, 2018, s. 271), dlatego ich złe samopoczucie, rozwój jakiejś choroby mogą być zamaskowane. Podobny efekt może dawać niechęć do kontaktów z innymi, w tym lekarzami. Łatwo zatem przeoczyć stan wskazujący na kłopoty ze zdrowiem.

Nieco inaczej wygląda sytuacja ze zdrowiem psychicznym i kondycją intelektualną. Kobieta dostrzega u siebie słabszą pamięć oraz wrażenie spowolnienia intelektualnego. Nie pamiętam już wszystkiego, mój mózg potrzebuje więcej czasu żeby coś przyjać i przetworzyć, ale to nawet dobrze, jak coś się trochę wolniej dzieje, gdzie się spieszyć? Można także przypuszczać, że niechęć do większej aktywności i obniżony nastrój mogą być przejawem depresji, która niekiedy towarzyszy zaburzeniom zespołu Aspergera. Kiedyś się może więcej chciało, tak poukładać, posegregować, a dzisiaj to mniej trochę, raczej posiedzieć wolę i nic nie robić, tak patrzeć przed siebie lubię.

Zachowanie zdrowia dla badanej jest ważne. Chętnie czyta publikacje dotyczące zdrowego żywienia, ogląda programy telewizyjne o tej tematyce, kupuje produkty uznane za zdrowe, przygotowuje samodzielnie posiłki. Można powiedzieć, że jest to jej główne (być może jedyne) zainteresowanie. Nie uprawia jednak żadnej aktywności fizycznej i nie przywiązuje do tego wagi. Dbanie o zdrowe odżywianie nie niesie ze sobą innych elementów zdrowego 
stylu życia i dbałości o inne sfery. Badana jest bardzo szczupła, ubiera się dość niedbale i niezbyt dba o wygląd.

Kobieta aktualnie spostrzega siebie w sposób pozytywny i akceptujący: Moim zdaniem to ja sie niewiele zmieniłam, oczywiści troche włosy, twarz $i$ tak dalej, ale $w$ środku ta sama i tak zostanie na pewno do śmierci. Nie pragnie zmian, nie oczekuje ich i raczej dąży do utrzymania swojej rzeczywistości w niezmiennej strukturze: Ja bym niczego nie zmieniła $w$ swoim życiu, ani wcześniej, ani teraz, mi jest tak dobrze i życzę sobie, chcę tego, żeby się nic nie zmieniato. Moje życie jest dobre i lubię tak, jak jest teraz.

\section{Próba wnioskowania}

Opisany przypadek 65-letniej kobiety z zespołem Aspergera jest jedynie jednostkowym przykładem osoby starszej z taką diagnozą. Materiał badawczy pozwolił na opis i charakterystykę oraz wnioskowanie, którego nie da się uogólnić na szerszą populację. Brakuje badań naukowych skoncentrowanych na tej problematyce, dlatego warto się przyjrzeć nawet jednostkowym sytuacjom. Badanie można potraktować jako pilotażowe, będące inspiracją do dalszych eksploracji. Starzejących się osób z zespołem Aspergera będzie coraz więcej, co rodzi potrzebę zgłębiania zjawiska ich przystosowania do ostatniej fazy życia.

Przystosowanie do starości, a więc i do zadań z niej wynikających, jest procesem, który dokonuje się wraz z pojawiającymi się deficytami, utratami, obniżeniem sprawności psychofizycznej. Ludzie starsi nie stanowią pod tym względem grupy jednolitej. Podobnie jak osoby z zespołem Aspergera, które również pod wieloma względami są zróżnicowaną populacją. Znaczna część to osoby, u których ZA zdiagnozowano już w dorosłym życiu, które dorastały nieświadome istnienia takiego zjawiska lub żyły z nietrafną, inną diagnozą. Trudno dziś powiedzieć, czy i w jaki sposób proces starzenia się wpływa na ludzi z ASD i czy oraz jak zespół Aspergera wpływa na proces starzenia się. Na pewno brakuje wiedzy na ten temat.

Powyższe badania wykazały, że u badanej:

1. cechy zespołu Aspergera widoczne są również w obecnej fazie życia w badanych sferach funkcjonowania;

2. widoczne są skutki procesu starzenia się w wymiarze fizycznym i psychicznym, co w pewnych zakresach uwidacznia się w jej funkcjonowaniu;

3. skutki starzenia się w wymiarze funkcjonowania społecznego są trudne do określenia, bo brakuje możliwości oceny, czy są konsekwencją zaburzeń charakterystycznych dla zespołu Aspergera, czy procesu starzenia się; 
4. widoczne są utrwalone struktury zarówno zewnętrzne, jak i wewnętrzne mające znaczenie dla jej funkcjonowania w różnych sferach życia;

5. dominuje perspektywa akceptacji i satysfakcji z aktualnej sytuacji życiowej, co może być wynikiem utrzymania zdolności adaptacyjnych;

6. samotność nie jest źródłem cierpienia;

7. w aktualnej sytuacji zdrowotno-bytowej nie ma potrzeby wsparcia instytucjonalnego.

Analiza materiału badawczego pozwala na dostrzeżenie odniesień do różnych teorii starzenia się i przystosowania do starości. Jednak najsilniej uwidoczniona została pewna ciągłość w funkcjonowaniu kobiety na poszczególnych etapach życia. Robert D. Hill (2015) uważał, że na ciągłość tożsamości seniorów wpływa ich pogląd o sobie samych oraz okoliczności warunkujące stabilność wyobrażeń, a więc na osobowość oddziałują dwa źródła - ciągłość wewnętrzna i ciągłość zewnętrzna. W wypowiedziach badanej można dostrzec symptomy ciągłości wewnętrznej, czyli poczucia ,ja”. Można przypuszczać, że badana $\mathrm{w}$ okresie starości posiada bardzo zbliżony repertuar cech osobowościowych jak w młodości ${ }^{9}$. Jej poglądy o sobie samej są spójne, ma poczucie własnej osoby tu i teraz, co może być obrazem ,ja” z przeszłości. U badanej uwidoczniono cechy przystosowania do starości charakterystyczne dla teorii ciągłości - świadomość siebie, ustabilizowany obraz świata, specyficzna filozofia życiowa - to struktura wewnętrzna, która determinuje selekcjonowanie informacji i podejmowanie decyzji.

Wewnętrzne cechy badanej mogą też decydować o jej zdolnościach adaptacyjnych i zdolności przystosowywania się do ewentualnych zmian. U kobiety obecna jest przewidywalność zachowania, na podstawie wcześniej wyznaczonych wartości, upodobań, preferencji, które najprawdopodobniej wynikają również z zaburzeń związanych z ZA. Dla niej samej wydaje się to być warunkiem utrzymania psychologicznego bezpieczeństwa. Wcześniejsze doświadczanie rzeczywistości przez pryzmat zespołu Aspergera, skłonności, ale też nabyte umiejętności związane z życiem z ZA oraz cechy osobowościowe ukształtowane we wcześniejszych etapach rozwoju stworzyły u badanej swoisty mechanizm przystosowawczy i pozwalają na satysfakcjonujące życie w starości.

Ciągłość zewnętrzna z kolei widoczna jest w niezmieniających się warunkach mieszkaniowych, niezmiennym stylu życia, skłonności do pozostawania $\mathrm{w}$ domu, otaczaniu się tymi samymi, uporządkowanymi przedmiotami,

\footnotetext{
${ }^{9}$ Potwierdzić by to można jedynie w badaniach podłużnych, które w tym przypadku nie są możliwe do zrealizowania
} 
co stanowi o jej odrębności, indywidualności i niepowtarzalności. Kobieta nie podejmuje nowych ról społecznych, ani nowych aktywności, ale kontynuuje te, które realizuje od dawna (np. robi zakupy, systematycznie odwiedza bibliotekę). Te elementy tworzą pewną spójną całość, tworząc w świadomości badanej swoistą reprezentację. Ciągłość zewnętrzna i wewnętrzna wydają się stanowić dla badanej podstawę utrzymania własnego obrazu siebie i swojego życia oraz dają siły wzmacniające w przeżywaniu starości.

Jak pisze Muszyński, teoria ciągłości zwraca szczególną uwagę na doświadczenia, umiejętności, skłonności, a także na cechy osobowościowe. W przypadku badanej kobiety wpływ na doświadczanie rzeczywistości i kształtowanie osobowości miały na pewno skutki zaburzeń wynikających z zespołu Aspergera. Bez względu jednak na to posiada ona niezależność i zdolność do zaspokojenia swoich potrzeb zarówno na płaszczyźnie fizycznej, jak i psychicznej.

\section{ZAMIAST PODSUMOWANIA}

Z pewnością starość nie eliminuje cech zespołu Aspergera, ale nie wiemy też, czy je wzmacnia. Konieczne są zatem badania, ponieważ liczba starzejących się osób z ZA będzie wzrastać, a rozpoznanie zjawiska pozwoli na ewentualne i wczesne wdrażanie strategii minimalizowania konsekwencji tego zaburzenia w życiu seniorów.

Należy jednak zauważyć, że choć życie osób z zespołem Aspergera osobom neurotypowym wydawać się może skomplikowane, trudne czy monotonne, to nie zawsze taka ocena musi być słuszna. Opisana kobieta swoje życie ocenia jako udane i satysfakcjonujące. Jest pogodzona ze sobą i akceptuje to, kim jest. Jak mówi: thum nie gwarantuje dobrego samopoczucia i zadowolenia z życia. Sama dokonuje wyborów, rezygnuje z kontaktów, wykazuje niechęć do poruszania się, do podtrzymywania relacji z rodziną czy sąsiadami. Nie chce niczego zmieniać i niczego nie oczekuje. Nawet jeżeli jest to postawa będąca skutkiem cech charakterystycznych dla zespołu Aspergera czy utrwalonych przez lata schematów, nawyków, to należy brać ją pod uwagę w przypadku oferowania pomocy i wsparcia. Samotny zmierzch życia nie musi być bolesny, nawet jeśli taki się jawi. Samotność w starości, tak jak w przypadku badanej, może dawać spokój i równowagę, a wewnętrznie zbudowany świat - być źródłem bezpieczeństwa. Być może w imię pełnej przynależności do społeczeństwa nie warto zmuszać ludzi do zachowań, które są wbrew ich naturze, potrzebom, oczekiwaniom. Należy pamiętać, że każdemu człowiekowi przypisane są określone zdolności do wartościowania 
i wyboru preferencji najbardziej dla niego optymalnych. Może warto pozwolić osobom z zespołem Aspergera wybrać własną drogę również starzenia się i przeżywania starości, bo właśnie ona może okazać się dla nich tą właściwą.

Jednocześnie trzeba pamiętać, że jest to przypadek jednostkowy i zapewne, z uwagi na złożoność zjawiska i różnorodność populacji osób z zespołem Aspergera, inne starzejące się osoby $\mathrm{z}$ podobną diagnozą mogą być $\mathrm{w}$ zupełnie odmiennej sytuacji. Nie można zatem pomijać faktu, że brakuje strategii zaradczych dostępnych dla osób starszych z zespołem Aspergera. W grupie tej zapewne są i będą tacy, dla których starzenie się i związane z tym ewentualne trudności okaże się wyzwaniem nie tylko dla nich samych, ale i dla instytucji pomocowych.

\section{BIBLIOGRAFIA}

ATCHLEY, R.C. (1989). A Continuity Theory of normal aging. The Gerontologist, 29(2), 183-190.

Atтwood, T. (2013). Zespół Aspergera. Kompletny przewodnik. Gdańsk: Harmonia.

Attwood, T. (2006). Zespót Aspergera. Poznań: Zysk i S-ka.

Delacato, C.H. (1995). Dziwne, niepojęte. Autystyczne dziecko. Warszawa: Fundacja Synapsis.

DSM V, American Psychiatric Assotiation, Washington (tłumaczenie fragmentu).

Frith, U. (2008). Autyzm. Wyjaśnienie tajemnicy. Gdańsk: Gdańskie Wydawnictwa Psychologiczne.

GrZywacz, K. (2013). Diagnostic and Statistical Manual of Mental Disorders (Fifth Edition).

HALIK, J. (2002). Zdrowotne skutki starzenia się społeczeństwa polskiego. W: J. HALIK (red.), Starzy ludzie w Polsce: spoleczne i zdrowotne skutki starzenia się spoteczeństwa. Warszawa: Instytut Spraw Publicznych.

HENDRICKX, S. (2018). Kobiety i dziewczyny ze spektrum autyzmu. Od wczesnego dzieciństwa do późnej starości. Kraków: Wydawnictwo UJ.

Hill, R.D. (2015). Pozytywne starzenie się. Młodzi duchem w jesień życia. Warszawa: Laurum.

KANNER, L. (1968). Autistic disturbances of affective contact. Acta Paedopsychiatrica, 35(4), 100-136.

Kozdroń, A. (2015). Zespót Aspergera. Zrozumieć, aby pomóc. Warszawa: Difin.

Maciarz, A., Biadasiewicz, M. (2005). Dziecko autystyczne z zespołem Aspergera. Kraków: Impuls.

MuSZYŃSKI, M. (2017). Teoria ciągłości. W: Encyklopedia starości, starzenia się i niepetnosprawności (s. 50-53). Katowice : Stowarzyszenie Thesaurus Silesiae - Skarb Śląski.

PIsula, E. (2012). Autyzm. Od badań mózgu do praktyki psychologicznej. Gdańsk: GWP.

REMBOWsKI, J. (1984). Psychologiczne problemy starzenia się człowieka. Warszawa: PWN.

Rimland, B. (1994). Intensive early behavioral intervention: a letter of support. Autism Research Review International, 8,3, http://www.autism.com/ari/editorial/support.html (dostęp: 20.02.2020).

RyNkiewicz, A. (2009). Zespół Aspergera. Inny mózg, inny umyst. Gdańsk: Harmonia.

RYNKIEWICZ, A., KULIK, M. (2013). Wystandaryzowane, interaktywne narzędzia do diagnozy zaburzeń ze spektrum autyzmu a nowe kryteria diagnostyczne DSM-5. Psychiatria, 10(2), 41-48. 
SŁAWIŃSKA, A. (2014). Zespół Aspergera u osób dorosłych - zbieżność z innymi zaburzeniami, zaburzenia współistniejące i problemy towarzyszące. Psychiatria i Psychologia Kliniczna, 14(4), 304-307.

SoKOŁowsKA, E. (2014). Osobowość seniora - dylematy ciągłości w świecie ponowoczesnym. Rocznik Andragogiczny, 21, 251-258.

STEFAŃSKA-KLAR, R. (2002). Charakterystyka zespołu Aspergera na tle innych zaburzeń autystycznego spektrum. Psychologia i Rzeczywistość, 4.

Steuden, S. (2011). Psychologia starzenia się i starości. Warszawa: PWN.

SZATMARI, P. (2007). Uwięziony umyst. Kraków: Znak.

ZAJĄC, L. (2002). Psychologiczna sytuacja człowieka starszego oraz jej determinanty. W: K. OBUCHOWSKI (red.), Starość i osobowość (s. 53-112). Bydgoszcz: Wydawnictwo Akademii Bydgoskiej im. Kazimierza Wielkiego.

\section{ZESPÓŁ ASPERGERA U OSOBY W OKRESIE PÓŹNEJ DOROSŁOŚCI ANALIZA PRZYPADKU}

\section{STRESZCZENIE}

W tekście opisano, na podstawie badań własnych, przypadek 65-letniej kobiety z zespołem Aspergera. Głównym celem badań było uzyskanie odpowiedzi na pytanie: jaka jest starość badanej kobiety z zespołem Aspergera? Artykuł rozpoczyna się od wprowadzenia teoretycznego w poruszaną problematykę, gdzie przedstawiono najważniejsze zagadnienia dotyczące zespołu Aspergera oraz starości i starzenia się z zaakcentowaniem teorii ciągłości. Następnie uwzględniono charakterystykę badanej kobiety w kontekście jej sytuacji rodzinnej, bytowej, edukacyjnozawodowej, zdrowotnej, relacji międzyludzkich. Artykuł kończą wnioski i podsumowanie. Należy przy tym podkreślić, że opisany przypadek, może być traktowany jedynie jako badanie pilotażowe i przygotowanie gruntu dla kolejnych eksploracji o szerszym zakresie.

Słowa kluczowe: zespół Aspergera; przypadek; starość; teoria ciągłości.

\section{ASPERGER'S SYNDROME IN A PERSON IN LATE ADULTHOOD. CASE STUDY}

\section{SUMMARY}

The text describes, based on own research, the case of a 65-year-old woman with Asperger's syndrome. The main aim of the research was to answer the question: what is the age of the examined woman with Asperger's syndrome? The article begins with a theoretical introduction to the discussed issues, where the most important issues concerning Asperger's syndrome and old age and aging are presented with emphasis on continuity theory. Next, the characteristics of the examined woman in the context of her family, living, educational and professional situation, health and interpersonal relations were taken into account. The article concludes with conclusions and a summary. It should be stressed that the described case can only be treated as a pilot study and preparation of the ground for further explorations of a wider scope.

Key words: Asperger's syndrome; chance; old age; continuity theory. 